\title{
The host-parasite relationship between the rainbow trout (Oncorhynchus mykiss) and the ectoparasite Argulus foliaceus (Crustacea: Branchiura): epithelial mucous cell response, cortisol and factors which may influence parasite establishment.
}

\author{
D.T. Nolan, A.L. van der Salm and S.E. Wendelaar Bonga \\ Department of Animal Physiology, Faculty of Science, University of Nijmegen, Toernooiveld 1, \\ 6525 ED Nijmegen, The Netherlands
}

Key words: ectoparasites, Argulus foliaceus, host-parasite interaction, Oncorhynchus mykiss, skin epidermis, cortisol, mucous cells, transmission electron microscopy.

\begin{abstract}
The effects of short-term infection with the branchurian crustacean ectoparasite Arguhus foliaceus, and the fish stress hormone cortisol (which is reported to stimulate mucus discharge), were studied on the mucous cell population of the head skin of rainbow trout (Oncorhynchus mykiss). Argulus infection did not raise plasma cortisol significantly and had no effect on the number of epidermal mucous cells in the head skin. Cortisol was administered twice to groups of trout via the food, significantly elevating circulating plasma cortisol at $24 \mathrm{~h}$ post feeding without affecting numbers of mucous cells, and increasing the numbers of vesicles in the upper cells of the epidermis. Subsequent infection with the parasite (6 Argulus/fish) did not affect either plasma cortisol or total numbers of mucous cells at $48 \mathrm{~h}$ post-infection with the parasite, but led to a significantly lower parasite infestation per fish in the cortisol-administered groups. A $24 \mathrm{~h}$ culture system was used to expose pieces of trout skin to $50 \mathrm{ng} / \mathrm{ml}$ cortisol in vitro to investigate whether cortisol alone would stimulate reductions in mucous cell numbers. These were unaffected by the addition of cortisol. The in vivo and in vitro results are discussed in relation to the current understanding of crustacean host-parasite interactions.
\end{abstract}

$\begin{array}{lr}\text { Contents } & \\ & \\ \text { Introduction } & 57 \\ \text { Materials and methods } & 58 \\ \text { In vivo Argulus infection experiment } & 58 \\ \text { In vitro head skin incubations with cortisol } & 58 \\ \text { Sample processing } & 59 \\ \text { Statistical analysis } & 59 \\ \text { Results } & 59 \\ \text { In vivo Argulus infection experiment } & 59 \\ \text { In vitro head skin incubations with cortisol } & 61 \\ \text { Discussion } & 61 \\ \text { Acknowledgements } & 62 \\ \text { References } & 62\end{array}$

\section{Introduction}

The Caligidae and Argulidae teleost crustacean ectoparasités are serious parasites of fish under natural, culture and managed situations (Heckmann, 1993). Although much research has been carried out on species of the marine Caligidae (Boxshall \& Defaye, 1993), comparatively little attention has focused on species of the Argulidae. Nevertheless, Argulus species have been implicated in the collapse of a rainbow trout stock (Menezes et al., 1990) and are problematic in carp farming operations (Singhal et al, 1990). These ectoparasites are not host-specific and can live on a variety of host species (Lamarre \& Cochran, 1992) and have, therefore, good potential to spread.

The skin epithelium of the host fish, the target for crustacean ectoparasite attachment and feeding, is a complex epithelium comprised of several layers of cells which are continuous over the body surface (Whitear, 1986). The skin epithelium (including that of the gill) forms the first vital barrier between the external and the internal environment and is protected with a chemically and functionally complex mucous coat which is discharged by specialized mucous cells in the epidermis (Shephard, 1994). Mucus discharge has been evoked by cortisol administration in vivo (Iger et al., 1995). The correct functioning of these mucous cells is essential for maintaining the protective mucus layer on the body surface of the fish. The epidermal structure changes in fish in response to a wide variety of stressors, including crustacean ectoparasites 
(Johnson \& Albright, 1992a, MacKinnon, 1993, Nolan et al., 1998b).

A key factor which can affect the health status of fish and increase susceptibility to disease is stress (Wedemeyer, 1997). The topic of stress in fish is complex, but levels of the primary stress hormone cortisol are elevated in the blood of stressed fish and the effects of toxic and non-toxic stressors on fish can be severe and lead to immunosuppression, reduced growth and reproduction (for review, see Wendelaar Bonga, 1997). Links between stress and crustacean ectoparasite infestation have been made (Noga et al., 1991, Johnson et al., 1996) and recently reviewed (MacKinnon, 1998). Johnson \& Albright, (1992b) have shown that cortisol administration influenced the host-parasite interaction in coho salmon (Oncorhynchus kisutch) and increased susceptibility to infection with Lepeophtheirus salmonis by suppressing inflammatory response and epithelial hyperplasia in the skin. Stress-related changes have also been reported in the skin of cortisol-fed rainbow trout, including stimulation of mucous cell discharge in the epidermal cells of the head region (Iger et al,, 1995). Infection of Atlantic salmon with numbers of the sea louse $L$, salmonis strongly reduced mucous cell numbers in the skin at $24 \mathrm{~h}$ post-infection (Nolan et al., 1998b).

In the present study, mucous cell numbers from the head region of rainbow trout have been studied in response to crustacean ectoparasite infestation and the role of the stress hormone cortisol has been examined in vivo and in vitro. Immature rainbow trout, including one treatment administered cortisol via the food, were infected with Argulus foliaceus (6 parasites/fish), and the total numbers of mucous cells in the head skin were quantified at $24 \mathrm{~h}$ post cortisol feeding and $48 \mathrm{~h}$ post parasite infection by light microscopy. The effects of the cortisol administration were assessed by measuring plasma cortisol and examination of the skin epidermis by electron microscopy. Numbers of parasites per fish were also counted for all treatments. To determine whether mucous cell numbers were influenced by cortisol, biopsies of skin from the trout head were also incubated for $24 \mathrm{~h}$ in vitro in the presence of cortisol, and the total number of mucous cells quantified.

\section{Materials and methods}

\section{In vivo Argulus infection experiment}

Three treatment groups of $70 \mathrm{~g}$ rainbow trout were each set up in duplicate in 651 black plastic tanks containing $\mathbf{3 0}$ fish as described by Ruane et al. (1999). After 2 weeks acclimation, two groups were fed cortisol-containing food (100 mg/kg food) on 2 alternate days 72 and $24 \mathrm{~h}$ pre-sampling. The third group received food sprayed with the ethanol vehicle only. The fish were sampled at $24 \mathrm{~h}$ after the second cortisol-containing meal. Two treatments (cortisol fed and normal diet) were then infected with numbers of sub-adult and adult $A$. foliaceus (6 parasites/fish) and sampled at $48 \mathrm{~h}$ post infection.

Ten fish from each treatment (comprised of 5 fish from each duplicate tank) were sampled $24 \mathrm{~h}$ after feeding the second cortisol-containing diet. Fish were irreversibly anaesthetized in 2phenoxyethanol (1:1000; Sigma) and blood was withdrawn by needle from the caudal blood vessels and vortexed in eppendorf tubes with $\mathrm{Na}$,EDTA/apoprotinin $(1.5 \mathrm{mg} / 3000 \mathrm{KIU}$ per $\mathrm{ml}$ blood; Sigma) on ice for cortisol analysis. Samples of skin from the head were fixed in Bouin's fixative for light microscopy (all groups) and 3\% glutaraldehyde buffered in Na-cacodylate $(0.09 \mathrm{M}, \mathrm{pH}$ 7.3) with post-fixation in $1 \%$ osmium tetroxide in the same buffer for electron microscopy (control and cortisol fed fish at $24 \mathrm{~h}$ post cortisol feeding only), as described by Nolan et al. (1998b). The body of each fish was thoroughly examined and numbers of parasites on the body surface were recorded for each fish.

\section{In vitro head skin incubations with cortisol}

Explants of head skin measuring approximately 20 $\times 20 \mathrm{~mm}$ were sampled from 8 irreversibly anaesthetized rainbow trout, washed three times in PBS for 5 min each wash before being bisected. One piece from each fish was then placed in $5 \mathrm{ml}$ of a complete fish skìn culture medium (Mothersill et al., 1995) and the second in $5 \mathrm{ml}$ of the same culture medium with the further addition of $50 \mathrm{ng} / \mathrm{ml}$ cortisol (Hydrocortisone; Sigma). After $24 \mathrm{~h}$ in- 
Table 1. Plasma cortisol (ng/ml), total number of epidermal mucous cells (no. cells/300 $\mathrm{mm}$ ) in the head skin, and infestation levels of the rainbow trout (Oncorhynchus mykiss) $24 \mathrm{~h}$ after cortisol feeding and $48 \mathrm{~h}$ after subsequent infection with Argulus foliaceus (6 parasites/fish).

\begin{tabular}{|c|c|c|c|}
\hline Treatment & × Plasma cortisol & $\begin{array}{l}\text { Epidermal mucous } \\
\text { cells }\end{array}$ & $\begin{array}{l}\text { Number Argulus/ } \\
\text { gram fish }\end{array}$ \\
\hline \multicolumn{4}{|l|}{$24 \mathrm{~h}$ post-treatment } \\
\hline 1. control (ethanol-sprayed) & $2.3 \pm 0.7$ & $18 \pm 1.5$ & 0 \\
\hline 2. + cortisol & $27.6 \pm 7.6^{* * *}$ & $19 \pm 1.9$ & 0 \\
\hline 3. - (ethanol-sprayed) & $6.5 \pm 2.4$ & . $14 \pm 4.5$ & 0 \\
\hline \multicolumn{4}{|l|}{$48 \mathrm{~h}$ post-treatment } \\
\hline 1. control & $6.1 \pm 1.5$ & $16 \pm 2.5$ & 0 \\
\hline \multicolumn{4}{|l|}{ 2. + cortisol } \\
\hline + Argulus & $9.5 \pm 2.9$ & $17 \pm 2.3$ & $0.016 \pm 0.044^{*}$ \\
\hline 3. + Argulus & $12.2 \pm 3.2$ & $17 \pm 2.0$ & $0.050 \pm 0.011^{*}$ \\
\hline
\end{tabular}

$* * *$ significantly different from control at $P<0.001 ; "$ * significantly different from each other at $P<0.05$

cubation at room temperature, the skin samples were fixed for $24 \mathrm{~h}$ in Bouin's solution and processed for light microscopy.

\section{Sample processing}

For quantification of mucous cells, sections from each fish were stained with periodic acid-Schiff's stain to identify total mucous cells, and quantified as described by Nolan et al. (1998b). For transmission electron microscopy (TEM), fixed skin tissues were stained in uranyl acetate, ethanol-dehydrated and embedded in Spurr's resin. Sections cut perpendicularly to the skin surface were further stained with lead citrate and examined in a Joel 100 CXIl transmission electron microscope at $40 \mathrm{kV}$, (Nolan et al., 1998b). Plasma cortisol was measured by RIA validated for measurements in fish plasma (Balm \& Pottinger, 1995).

\section{Statistical analysis}

Data are expressed as means \pm S.E.M. for $n=10$ (in vivo Argulus experiment) and $\mathrm{n}=8$ (in vitro skin incubate experiment). For the in vivo experiment, as there were no differences between replicate tanks, pooled data were analyzed by ANOVA at each time point and significance between treatments compared with controls was assessed using the Bonferroni Multiple Comparisons test. For the in vitro experiment and the parasite count data from the Argulus experiment, differences between groups were tested using the Mann-Whitney $U$ test. In all cases, statistical significance was accepted at $P<0.05$.

\section{Results}

In vivo Argulus infection experiment

Plasma cortisol was significantly higher in the cortisol-fed groups sampled at $\mathbf{2 4} \mathrm{h}$ post cortisolfeeding compared with controls (Table 1). The plasma cortisol levels were similar in all groups sampled at $48 \mathrm{~h}$ post-infection with Argulus (Table 1). The number of parasites attached to the skin of fish which had been cortisol-fed was significantly lower than fish which had not been administered cortísol (Table 1). Total numbers of mucous cells were similar at both time points (Table 1). Examination of the skin by transmission electron microscopy revealed large numbers of vesicles in the pavement and filament cells of the upper epidermis in the cortisol-fed fish at $24 \mathrm{~h}$ compared with control fish (Fig. 1A \& 1B).

\section{In vitro head skin incubations with cortisol}

Total numbers of epidermal mucous cells were similar in cultured skin explants incubated in full cul- 

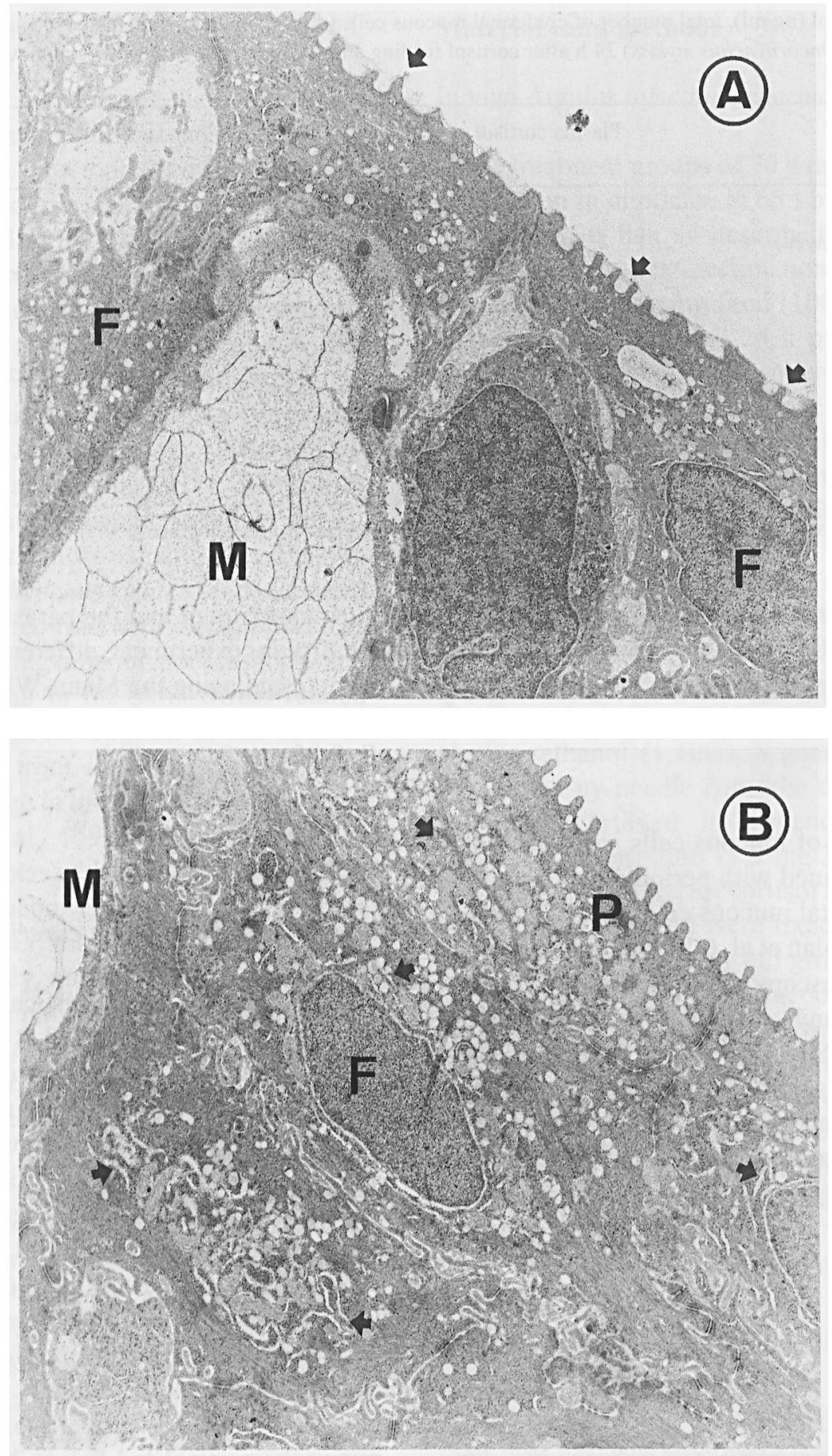

Fig. 1. Upper epidermis of the head skin of rainbow trout (Oncorhynchus mykiss). (A) Upper epidermis of control trout skin. The upper cell layer is comprised of differentiated pavement cells which have microridges apically (arrows). These cells, and the underlying filament cells $(\mathrm{F})$, contain low amounts of vesicles. Mature mucous cells $(\mathrm{M})$ are close to the surface, where they discharge their contents. (B) Upper epidermis of cortisol-fed trout skin, 24h post second cortisol feed (see text for details). The pavement (P) and filament (F) cells contain large amounts of vesicles. There is much endoplasmic reticulum visible in each cell (arrows) as more vesicles are synthesized. Both micrographs $\times 5500$. 
ture medium with and without an additional $50 \mathrm{ng} /$ $\mathrm{ml}$ cortisol (full culture medium 30 \pm 8.9 ; full culture medium plus $50 \mathrm{ng} / \mathrm{ml}$ cortisol 52 \pm 10.8 : (mean \pm SEM) number of mucous cells per $600 \mathrm{~mm}$ epidermis, $\mathrm{n}=8, P>0.05$.

\section{Discussion}

This study examines the short-term interaction between the crustacean ectoparasite, $A$. foliaceus and the host fish at the level of the skin epithelium. This is the first attempt to investigate the role of a host endocrine factor in the response to Argulus infection by combining in vivo and in vitro experimentation. Epithelial responses of fish to infection with caligid crustacean ectoparasites have been reported in salmonids in seawater (Johnson \& Albright, 1992a, MacKinnon, 1993) and result in increased mucus discharge and reduced numbers of mucous cells in the epidermis of the head skin within $24 \mathrm{~h}$ (Nolan et al., 1998b). In the present study using Argulus, total numbers of mucous cells were unaffected by the parasite or by cortisol feeding prior to parasite infection. This may be related to the different osmotic environments, as the present study was carried out in freshwater. Mucous cells were also quantitatively unaffected after freshwater exposure of Salmo trutta trutta to polluted water from the lower river Rhine (Nolan et al., 1998a).

The mucous cell populations studied by electron microscopy are affected by stressors, including crustacean ectoparasites (Nolan et al., 1998b). The effects include increased rate of mucus discharge, increased differentiation of new mucous cells and discharge of immature mucous cells (indicating increased turnover rate in the mucous cell population), as well as changes in the composition of mucosomes. Similar results have been reported following cortisol administration (Iger et al., 1995). The influence of cortisol therefore, may not be manifest in the absolute numbers of mucous cells present in the epidermis, but in the composition of the mucus or the stimulation of increased mucus discharge and differentiation of new mucous cells, increasing cell turnover within the mucous cell population as a whole, while overall absolute numbers remain constant. The lower number of para- sites present on trout groups which had previously been fed with cortisol suggests that the composition of the mucous layer at the body surface may have resulted in a less favourable environment and lower establishment rate of the parasite.

Infection of rainbow trout with $6 \mathrm{~A}$. foliaceus per fish did not significantly elevate plasma cortisol levels at $48 \mathrm{~h}$ post-infection. Ectoparasites have co-evolved with their host species and may not evoke a cortisol response in the low numbers used in this experiment. Increased cortisol levels may have occurred within the $48 \mathrm{~h}$ immediately post-infection and before sampling. Elevated plasma cortisol levels in Argulus-infested rainbow trout have been reported $48 \mathrm{~h}$ after a $4 \mathrm{~h}$ confinement stress (Ruane et al., 1998) indicating that effect of ectoparasites may not be seen immediately after infection, but become apparent when the response to a second stressor is investigated. It is also possible that a higher clearance rate of cortisol from the blood by target tissues (such as the skin) during infection and attachment of the parasite may be the explanation for the absence of a significant rise in cortisol in our experiment.

Cortísol feeding increased plasma cortisol levels but did not affect the epidermal mucous cell population or the mucous cell response to Argulus infection. Electron microscopy indicated stimulation of vesicle synthesis in the upper epidermal cell populations. This response has been shown to be evoked by cortisol administration (Iger et al., 1995) and must confer some advantage on the host during stress, perhaps contributing to the lower parasite numbers on cortisol-fed fish. Alterations in vesicle composition of the epidermal cells have also been reported for Salmo salar following infection with $L$. salmonis (Nolan et al., 1998b).

In vitro incubation of the head skin for $24 \mathrm{~h}$, with and without additional cortisol, did not stimulate a reduction in the total numbers of mucous cells. This culture medium supports the growth and differentiation of fish skin explants in the longer term (Mothersill et al., 1995). Perhaps $50 \mathrm{ng} / \mathrm{ml}$ cortisol was too low, as it reflected the circulating cortisol levels in the fish post-cortisol feeding, but the expected maximum peaks immediately postfeeding following Barton et al. (1987) would be around $100 \mathrm{ng} / \mathrm{ml}$. To address this issue, a dose 
response study to cortisol is required for $24 \mathrm{~h}$ skin explants incubated under these conditions. Ideally, following from the discussion above in relation to turnover within a mucous cell population, measuring cell proliferation in parallel may greatly help to resolve the data obtained.

In conclusion, infection of rainbow trout with 6 A. foliaceus per fish did not induce elevated cortisol levels in the blood at $48 \mathrm{~h}$ post-infection nor reduce the total numbers of mucous cells in the epidermis of the head skin. Prior cortisol administration to the fish elevated blood cortisol levels, stimulated vesicle synthesis in the upper epidermal cells, and resulted in reduced numbers of the parasite at $48 \mathrm{~h}$ post-infection without influencing the outcome of parasite challenge with respect to numbers of mucous cells. In vitro $24 \mathrm{~h}$ incubation of pieces of head skin with physiologically relevant cortisol levels $(50 \mathrm{ng} / \mathrm{ml})$ resulted in similar numbers of mucous cells compared with controls. We conclude that this low level of infection with Argulus does not increase plasma cortisol levels nor stimulate mucus discharge such that numbers of mucous cells are depleted in the short-term. Cortisol administrations in vivo reduce parasite establishment and this is correlated with vesicle synthesis in the cells of the upper epidermis of the host.

\section{Acknowledgements}

The authors are grateful to F.A.T. Spanings for provision of animals, experimental set-up and animal care and to J.C.A. van der Meij (electron microscopy) and A.J.M. Coenen (light microscopy) for technical assistance.

\section{References}

Balm PHM, Pottinger TG. 1995. Corticotrope and melanotrope POMC-derived peptides in relation to interrenal function during stress in rainbow trout (Oncorhynchus mykiss). Gen. Comp. Endocrinol. 98: 279-288.

Barton BA, Schreek CB, Barton LD. 1987. Effects of chronic cortisol administration and daily acute stress on growth, physiological conditions, and stress responses in juvenile rainbow trout. Dis. Aquat. Org. 2: 173-185.

Boxshall GA, Defaye D. 1993. Pathogens of wild and farmed fish: Sea Lice. Chichester: Ellis Horwood.

Heckmann RA. 1993. Parasites of salmonid fishes. In: Stoskopf MK, ed. Fish Medicine. Phìladelphia: W.B. Saunders, 408-428.
Iger Y, Balm PHM, Jenner HA, Wendelaar Bonga SE. 1995. Cortisol induces stress-related changes in the skin of rainbow trout (Oncorhynchus mykiss). Gen. Comp. Endocrinol. 97: 188-198.

Johnson SC, Albright LJ. 1992a. Comparative susceptibility and histopathology of the response of naive Atlantic, chinook and coho salmon to experimental infection with Lepeophtheirus salmonis (Copepoda: Caligidae), Dis. Aquat. Org. 14: 179-193.

Johnson SC, Albright LJ. 1992b. Effects of cortisol implants on the susceptibility and the histopathology of the responses of naive coho'salmon Oncorhynchus kisutch to experimental infection with Lepeophtheirus salmonis (Copepodax Calígidae). Dis. Aquat. Org. 14: 195-205.

Johnson SC, Blaylock RB, EIphick J, Hyatt KD. 1996. Disease înduced by the sea louse (Lepeophtheirus salmonis) (Copepoda: Caligidae) in wild sockeye salmon (Oncorhynchus nerka) stocks of Alberni Inlet, British Colombia. Can. J. Fish. Aquat. Sci. 53: 2888-2897.

Lamarre E. Cochran PA. 1992. Lack of host species selection by the exotic parasitic crustacean, Argulus japonicus. J. Freshwater Ecol. 7: 77-80.

MacKinnon BM. 1993. Host response of Atlantic salmon (Salmo salar) to infection by sea lice (Caligus elongatus). Can. J. Fish. Aquat. Sci. 50: 789-792.

MacKinnon BM. 1998. Host factors important in sea lice infections. ICES J. Mar. Sci.. 55: 188-192.

Menezes J, Ramos MA, Pereira TG, da Silva AM. 1990. Rainbow trout culture failure in a small lake as a result of massive parasitosis related to careless fish introductions. Aquaculture 89: 123-126.

Mothersill C, Lyng F, Lyons M, Cottell D. 1995. Growth and differentiation of epidermal cells from the rainbow trout established as explants and maintained in various media. J. Fish Biol. 46: 1011-1025.

Noga EJ, Wright JF, Levine JF, Dykstra MJ, Hawkins JH. 1991. Dermatological diseases affecting fishes of the Tar-Pamlico estuary, North Carolina (USA). Dis. Aquat. Org. 10: 87-92.

Nolan DT, Hadderingh RH, Jenner HA, Wendelaar Bonga SE. 1998a. The effects of exposure to Rhine water on the sea trout smolt (Salmo trutta trutta $\mathrm{L}_{\mathrm{x}}$ ): an ultrastructural and physiological study. In: Nienhuîs $\mathrm{PH}$, Leuven RSEW, Ragas AMJ, eds. New concepts for the sustainable management of river basins. Amsterdam: Backhuys, 261-271.

Nolan DT, Reilly P, Wendelaar Bonga SE. 1998b. Infection with low numbers of the sea louse Lepeophtheirus salmonis (Krøyer) induces stress-related effects in postsmolt Atlantic salmon (Salmo salar L.). Can. J. Fish. Aquat. Sci. Accepted.

Ruane NM, Nolan D', Rotllant J, Tort L, Balm PHM, Wendelaar Bonga SE. 1999. Modulation of the response of rainbow trout (Oncorhynchus mykiss Walbaum) to confinement by an ectoparasitic (Argulus foliaceus L.) infestation and cortisol feeding. Fish Physiol. Biochem, 20: 43-51.

Shephard KL: 1994. Functions for fish mucus. Rev. Fish Biol. Fisheries 4: 401-429. 
Singhal RN, Jeet S, Davies RW. 1990. The effects of argulosis-saprolehniasis on the growth and production of Cyprinus carpio. Hydrobiol, 202: 27-32.

Wedemeyer GA. 1997. Effects of rearing conditions on the health and physiological quality of fish in intensive culture. In: Iwama GK, Pickering AD, Sumpter JP, Schreck CB, eds. Fish Stress and Health in Aquaculture. Cambridge University Press, 35-71.
Wendelaar Bonga SE. 1997. The stress response in fish. Physiol. Rev. 77: 591-625.

Whitear M. 1986. The skin of fishes including cyclostomes - Epidermis. In: Bereiter-Hahn J, Matoltsy AG, Ríchards $\mathrm{KS}$, eds. Biology of the integument. Heidelberg: SpringerVerlag, 8-38.

Received: 4 December 1998 